\title{
REFUNDACJA LEKÓW A RÓWNY DOSTĘP DO ŚWIADCZEŃ OPIEKI ZDROWOTNEJ
}

\section{WPROWADZENIE}

Wejściu w życie ustawy z 12 maja 2011 r. o refundacji leków, środków spożywczych specjalnego przeznaczenia żywieniowego oraz wyrobów medycznych ${ }^{1}$ towarzyszył szum medialny i niepokój beneficjentów systemu opieki zdrowotnej, związany z tzw. protestem pieczątkowym. Dyskusja dotycząca obowiązków lekarzy wystawiających recepty i realizujących je aptekarzy oraz związanej z tym odpowiedzialności tych podmiotów wobec NFZ zupełnie przysłoniła bowiem zasadniczy cel ustawy refundacyjnej, którym było uporządkowanie problematyki refundowania ze środków publicznych leków, środków spożywczych specjalnego przeznaczenia żywieniowego oraz wyrobów medycznych. Trzeba w tym kontekście podkreślić, że omawiana ustawa dokonała w zakresie swojej regulacji wdrożenia dyrektywy Rady 89/105/EWG z 21 grudnia 1988 r. dotyczącej przejrzystości środków regulujących ustalanie cen na produkty lecznicze przeznaczone do użytku przez człowieka oraz włączenia ich w zakres krajowego systemu ubezpieczeń zdrowotnych ${ }^{2}$. Można bowiem uznać, że ustawa umożliwia uzyskanie ogólnego obrazu krajowych uzgodnień dotyczacych mechanizmu ustalania cen, z uwzględnieniem sposobu, w jaki kształtuje się on w określonych przypadkach, oraz wszelkich kryteriów, na jakich się opiera, co zgodnie z preambuła jest celem tej dyrektywy.

Należy zatem wskazać, że ustawa z 12 maja 2011 r. określa zasady, warunki i tryb podejmowania decyzji administracyjnej o objęciu refundacją leku, środka spożywczego specjalnego przeznaczenia żywieniowego, wyrobu medycznego i uchylenia tej decyzji; zasady finansowania leku, środka spożywczego specjalnego przeznaczenia żywieniowego, wyrobu medycznego objętych decyzją refundacyjna, kryteria tworzenia poziomów odpłatności i grup limitowych leków, środków spożywczych specjalnego przeznaczenia żywieniowego, wyrobów medycznych objętych decyzja refundacyjna, zasady i tryb oraz kryteria ustalania urzędowych cen zbytu na leki, środki spożywcze specjalnego przeznaczenia żywieniowego, wyroby medyczne, a także wysokość urzędowych marż hurtowych i urzędowych marż detalicznych; zasady ustalania cen leków

${ }^{1}$ Dz. U. 2011, Nr 122, poz. 696 ze zm. (dalej jako: ustawa refundacyjna, u.r.).

${ }^{2}$ Dz. Urz. WE L 40 z 11 lutego 1989 r., s. 8; Dz. Urz. UE Polskie wydanie specjalne, rozdz. 5, t. 1, s. 345 . 
oraz środków spożywczych specjalnego przeznaczenia żywieniowego stosowanych $\mathrm{w}$ ramach udzielania świadczeń gwarantowanych; zasady finansowania ze środków publicznych wyrobów medycznych przysługujących świadczeniobiorcom na zlecenie osoby uprawnionej; obowiązki aptek wynikające z obrotu lekami, środkami spożywczymi specjalnego przeznaczenia żywieniowego, wyrobami medycznymi, objętymi decyzją refundacyjna, a także zasady kontroli aptek oraz obowiązi osób uprawnionych do wystawiania recept na leki, środki spożywcze specjalnego przeznaczenia żywieniowego, wyroby medyczne, objęte decyzją refundacyjną.

W szczególności należy podkreślić, że ustawa refundacyjna wprowadziła tak istotne rozwiązania prawne, jak: całkowity budżet na refundację (przez co rozumieć należy wysokość środków publicznych przeznaczonych w planie finansowym Narodowego Funduszu Zdrowia, o którym mowa w art. 118 ustawy z 27 sierpnia 2004 r. o świadczeniach opieki zdrowotnej finansowanych ze środków publicznych, na refundowane leki, środki spożywcze specjalnego przeznaczenia żywieniowego, wyroby medyczne), który zgodnie z art. 3 ust. 1 u.r. nie może wynosić więcej niż 17\% sumy środków publicznych przeznaczonych na finansowanie świadczeń gwarantowanych w planie finansowym Funduszu, urzędową marżę hurtową w wysokości 5\% urzędowej ceny zbytu (art. 7 ust. 1 u.r.) oraz urzędową marżę detaliczną naliczaną od ceny hurtowej leku (art. 7 ust. 4 u.r.). Ustaliła kryteria tworzenia poziomów odpłatności i grup limitowych oraz kryteria podejmowania decyzji o objęciu refundacja i zasady ustalania urzędowej ceny zbytu (art. 10-16 u.r.), a także nakazała świadczeniodawcom nabywać leki, środki spożywcze specjalnego przeznaczenia żywieniowego, wyroby medyczne w celu realizacji świadczeń gwarantowanych po cenie nie wyższej niż urzędowa cena zbytu powiększona o marżę, nie wyższą niż urzędowa marża hurtowa, a w przypadku nabywania od podmiotu innego niż przedsiębiorca prowadzący obrót hurtowy w rozumieniu ustawy z 6 września 2001 r. - Prawo farmaceutyczne - po cenie nie wyższej niż urzędowa cena zbytu (art. 9 ust. 1 u.r.).

Przedmiotem niniejszego opracowania jest jednak równie ważna i godna podkreślenia okoliczność, że w ustawie tej należy także widzieć działanie władzy publicznej (ustawodawcy) zmierzające do urzeczywistnienia konstytucyjnego obowiązku zapewnienia obywatelom równego dostępu do świadczeń opieki zdrowotnej finansowanej ze środków publicznych (art. 68 ust. 2 zd. 1 Konstytucji RP). Należy przy tym zaznaczyć, że obowiazek ten oznacza coś więcej niż tylko uregulowanie wzajemnych relacji podmiotów w ramach systemu opieki zdrowotnej, stanowiące zadanie władzy ustawodawczej (art. 68 ust. 2 zd. 2 Konstytucji RP). Wynika z niego również nadzór nad funkcjonowaniem systemu, przy czym nadzór ten należy rozumieć dynamicznie, tj. nie tylko przez pryzmat wypełnienia ustawowych warunków, ale w kontekście realizacji zasady równego dostępu. Dynamizm ten oznacza m.in. konieczność regularnej ewaluacji istniejących rozwiązań prawnych i oceny zgodności skutków ich obowiązywania z założonymi celami, aby możliwe było wprowadzanie niezbędnych korekt na bieżąco ${ }^{3}$. W tym kontekście należy podkreślić

\footnotetext{
${ }^{3}$ Szerzej na temat kwestii zapewnienia równego dostępu jako zadania władz publicznych w kontekście koncepcji państwa gwarantującego por. D. E. Lach, Zasada równego dostępu do świadczeń opieki zdrowotnej, Warszawa 2011, s. 38-47.
} 
istotną zmianę dotyczącą zasad refundacji leków, środków spożywczych specjalnego przeznaczenia żywieniowego oraz wyrobów medycznych w nowej ustawie. Dotyczy ona nie tyle kwestii formalnych, ile zupełnego przeorientowania kryteriów decydujących o przypisaniu leku do określonych w ustawie poziomów odpłatności.

Zmiana ta jest na tyle znaczaca, że zasługuje na bliższe omówienie. Z tego względu w niniejszym opracowaniu w pierwszej kolejności przedstawiona zostanie pokrótce obowiązująca do 31 grudnia 2011 r. a dotycząca refundacji leków regulacja ustawy z 27 sierpnia 2004 r. o świadczeniach opieki zdrowotnej finansowanych ze środków publicznych ${ }^{4}$, aby na tym tle zaprezentować zasady przewidziane w ustawie refundacyjnej. Na zakończenie nowe przepisy o refundacji leków zostaną omówione w kontekście konstytucyjnego obowiąku zapewniania obywatelom równego dostępu do świadczeń opieki zdrowotnej finansowanej ze środków publicznych i jego dynamicznej realizacji.

\section{REGUŁY REFUNDACJI LEKÓW WEDŁUG USTAWY ZDROWOTNEJ}

Przepisy zawarte w rozdziale 2 działu II u.ś.o.z., zatytułowanym „Zakres świadczeń opieki zdrowotnej”, przewidujące udział świadczeniobiorców w kosztach udzielanych w fazie realizacyjnej świadczeń opieki zdrowotnej, regulowały m.in. odpłatność ryczałtową i częściową odnośnie do zaopatrzenia w leki (art. 36 u.ś.o.z.).

Wyjątkiem od zasady (współ)odpłatności pozostał, utrzymany w mocy przepisami ustawy refundacyjnej, przepis art. 35 u.ś.o.z., na mocy którego leki i wyroby medyczne zapewnia się bezpłatnie świadczeniobiorcy przyjętemu do szpitala lub innego ZOZ-u przeznaczonego dla osób potrzebujących całodobowych lub całodziennych świadczeń opieki zdrowotnej oraz przy wykonywaniu zabiegów leczniczych i pielęgnacyjnych, diagnostycznych i rehabilitacyjnych przez podmioty uprawnione do udzielania świadczeń, a także przy udzielaniu przez te podmioty pomocy w stanach nagłych, jednak tylko pod warunkiem, że owe leki i wyroby medyczne sa konieczne do wykonania świadczenia ${ }^{5}$. W komentarzu do ustawy celnie zauważono, że przepis art. 35 u.ś.o.z. nie nakłada na szpital nieograniczonego i bezwzględnego obowiązku zapewnienia pacjentowi wszelkich leków, w tym leków, które przyjmuje on w związku z chorobami przewlekłymi. We wspomnianej regulacji podkreśla się bowiem związek podawanych leków z wykonywanym świadczeniem - muszą być one niezbędne do jego wykonania oraz pozostawać w związku z przyczyną hospitalizacji oraz profilem leczniczym danego oddziału szpitalnego. Komentatorzy trafnie podnoszą w tym kontekście, że należy wykluczyć obowiązek finansowania np. leczenia immunosupresyjnego czy diabetologicznego w sytuacji, gdy „pacjent leczony jest z przyczyny niemającej związku ze schorzeniem będącym przyczyną zażywania leków. Nie wyklucza to jednak obowiązku zadbania, aby obec-

${ }^{4}$ Dz. U. 2008, Nr 164, poz. 1027 ze zm. (dalej jako: ustawa zdrowotna, u.ś.o.z.).

5 Por. na ten temat D. E. Lach, op. cit., s. 337-339. 
ność pacjenta w szpitalu nie spowodowała przerwania terapii” ${ }^{6}$. Podniesiono także, że na koszt szpitala - niezależnie od przyczyny hospitalizacji - powinno odbywać się leczenie, obejmujące zaopatrzenie w leki i wyroby medyczne, pewnych schorzeń współistniejących, które pojawiają się w trakcie hospitalizacji. Jako przykład wskazano na leczenie przeciwodleżynowe lub drobne infekcje nabyte w szpitalu, które wymagają np. podania antybiotyków ${ }^{7}$.

W sytuacjach innych niż wskazane w art. 35 u.ś.o.z. zaopatrzenie w leki było natomiast związane z częściową odpłatnościa, której wysokość, w zależności od ich rodzajów, określał art. 36 ust. 1 u.ś.o.z. W art. 5 pkt 10-12 u.ś.o.z. zdefiniowano rodzaje leków, wyodrębniane w art. 36 u.ś.o.z. z punktu widzenia wysokości odpłatności. Zgodnie z tymi definicjami lekiem podstawowym był produkt leczniczy ratujacy życie lub niezbędny w terapii dla przywracania lub poprawy zdrowia, spełniający warunki bezpieczeństwa, skuteczności i efektywności kosztowej, lekiem recepturowym natomiast produkt leczniczy sporządzony w aptece na podstawie recepty lekarskiej, z kolei lekiem uzupełniajacym był produkt leczniczy wspomagajacy lub uzupełniajacy działanie leków podstawowych, a także produkt leczniczy o zbliżonych właściwościach terapeutycznych do leku podstawowego. W kontekście niniejszych rozważań należy podkreślić, że podziału na poszczególne kategorie leków dokonano wyłącznie według kryterium medycznego - przeznaczenia leku.

Za leki podstawowe i recepturowe ${ }^{8}$ przewidziano odpłatność ryczałtowa, która zgodnie z art. 36 ust. 3 u.ś.o.z. nie mogła przekraczać 4,25 zł w przypad$\mathrm{ku}$ leku podstawowego oraz kwoty $12,74 \mathrm{zl}$ - leku recepturowego, przy czym kwoty te były w każdym roku waloryzowane średniorocznym wskaźnikiem cen towarów i usług konsumpcyjnych ustalonym w ustawie budżetowej. Odpłatność za leki uzupełniające ustalono natomiast w wysokości $30 \%$ albo $50 \%$ ceny leku. Wykaz leków podstawowych i uzupełniajacych oraz aktualną wysokość odpłatności za leki uzupełniające zawierało rozporządzenie wydane na podstawie upoważnienia z art. 36 ust. 5 u.ś.o.z. ${ }^{9}$

Artykuł 37 ust. 1 u.ś.o.z. stanowił, że świadczeniobiorcom chorującym na choroby zakaźne lub psychiczne oraz upośledzonym umysłowo, a także chorującym na niektóre choroby przewlekłe, wrodzone lub nabyte, leki i wyroby medyczne sa przepisywane bezpłatnie, za opłatą ryczałtową określoną w art. 36 ust. 1 pkt 1 u.ś.o.z. lub za częściową odpłatnością określoną w art. 36 ust. 1 pkt 2 u.ś.o.z. Wykaz chorób, o których mowa w pierwszym przepisie, a także wykaz leków i wyrobów medycznych dla każdej ze wskazanych chorób określało stosowne rozporządzenie ${ }^{10}$. Marginesowo jedynie można wskazać, że w litera-

${ }^{6} \mathrm{~K}$. Baka et al., Ustawa o świadczeniach opieki zdrowotnej finansowanych ze środków publicznych. Komentarz, Warszawa 2010, komentarz do art. 35 pkt 8.

7 Ibidem.

8 Przygotowywane zarówno z surowców farmaceutycznych, jak i z leków gotowych zamieszczonych w wykazach leków podstawowych i uzupełniających, pod warunkiem że przepisana dawka leku recepturowego była mniejsza od najmniejszej dawki leku gotowego w formie stałej stosowanej doustnie.

9 Rozporządzenie Ministra Zdrowia z 22 grudnia 2010 r. w sprawie wykazu leków podstawowych i uzupełniających oraz wysokości odpłatności za leki uzupełniające, Dz. U. Nr 251, poz. 1686.

${ }_{10}$ Rozporządzenie Ministra Zdrowia z 8 grudnia 2009 r. w sprawie wykazu chorób oraz wykazu leków i wyrobów medycznych, które ze względu na te choroby są przepisywane bezpłatnie, za opłatą ryczałtową lub za częściową odpłatnością, Dz. U. Nr 212, poz. 1647. 
turze podkreślano, iż ustawa nie zawiera własnych definicji choroby zakaźnej, choroby psychicznej, upośledzenia umysłowego oraz choroby przewlekłej, co oznaczało znaczną swobodę ministra zdrowia w określeniu zakresu świadczeń zdrowotnych finansowanych ze środków publicznych ${ }^{11}$.

Należy także zwrócić uwagę na art. 38 u.ś.o.z., w którym ustawodawca zdecydował się - w trosce o finanse systemu, ale i współpłacących świadczeniobiorców - na wprowadzenie limitów cen leków zawartych w wykazach leków podstawowych i uzupełniających oraz leków i wyrobów medycznych, które ze względu na choroby określone w art. 37 u.ś.o.z. przepisywane były bezpłatnie, za opłatą ryczałtową lub za częściową odpłatnością ${ }^{12}$. Limity te dotyczyły leków o tej samej nazwie międzynarodowej albo o różnych nazwach międzynarodowych, ale o podobnym działaniu terapeutycznym. Zgodnie z art. 38 ust. 3 u.ś.o.z. apteka mogła wydać lek, którego cena przekracza ustalony limit ceny, pobierała jednak w takiej sytuacji dopłatę w wysokości różnicy między ceną wydawanego leku a wysokością limitu ceny. Jak zauważono w komentarzu do ustawy, wysokość dopłaty, jaką mogła pobrać apteka, nie była nieograniczona. Artykuł 5 ust. 1 ustawy z 5 lipca 2001 r. o cenach ${ }^{13}$ stanowił $^{2}$ bowiem, że na produkty lecznicze i wyroby medyczne objęte wykazem leków podstawowych i uzupełniajaccych oraz wykazem leków i wyrobów medycznych przepisywanych bezpłatnie, za opłatą ryczałtową lub częściową odpłatnościa w związku z chorobami zakaźnymi lub psychicznymi, upośledzeniem umysłowym oraz niektórymi chorobami przewlekłymi, wrodzonymi lub nabytymi ustala się ceny urzędowe. Zgodnie w art. 9 wspomnianej ustawy ceny te miały charakter cen maksymalnych ${ }^{14}$.

Ustawodawca nałożył także na apteki obowiązek poinformowania świadczeniobiorcy o możliwości nabycia leku innego niż lek przepisany na recepcie, o tej samej nazwie międzynarodowej, dawce, postaci farmaceutycznej lub postaci farmaceutycznej zbliżonej, która nie powoduje powstania różnic terapeutycznych, i o tym samym wskazaniu terapeutycznym; cena takiego leku nie mogła przekroczyć limitu wyznaczonego przez cenę maksymalna. Apteka miała obowiązek posiadać ten lek, a na żądanie wydać go świadczeniobiorcy. Nie dotyczyło to jednak sytuacji, w której wystawiający receptę dokonał odpowiedniej adnotacji na druku recepty, wskazując na niemożność dokonania zamiany przepisanego leku.

\section{ZASADY REFUNDACJI LEKÓW WEDŁUG USTAWY REFUNDACYJNEJ}

Jak już wspomniano, ustawa refundacyjna reguluje m.in. zasady, warunki i tryb podejmowania decyzji administracyjnej o objęciu refundacja leku, zasady jego finansowania oraz kryteria tworzenia poziomów odpłatności

\footnotetext{
11 Szerzej na ten temat por. D. E. Lach, op. cit., s. 339-342.

12 Rozporządzenie Ministra Zdrowia z 8 grudnia 2009 r. w sprawie limitów cen leków i wyrobów medycznych wydawanych świadczeniobiorcom bezpłatnie, za opłatą ryczałtową lub częściową odpłatnością, Dz. U. Nr 212, poz. 1648.

13 Dz. U. Nr 97, poz. 1050 ze zm.

14 Por. K. Baka et al., op. cit., komentarz do art. 38 pkt 3.
} 
i grup limitowych leków. Wypada zaczać od wskazania, że zgodnie z art. 6 ust. 1 u.r. w odniesieniu do leków ustala się jedną z czterech kategorii dostępności refundacyjnej: 1) lek dostępny w aptece na receptę: a) w całym zakresie zarejestrowanych wskazań i przeznaczeń lub b) we wskazaniu określonym stanem klinicznym; 2) lek stosowany w ramach programu lekowego ${ }^{15}$; 3) lek stosowany w ramach chemioterapii: a) w całym zakresie zarejestrowanych wskazań i przeznaczeń lub b) we wskazaniu określonym stanem klinicznym oraz 4) lek stosowany w ramach udzielania świadczeń gwarantowanych, innych niż wymienione w pkt 1-3.

Jeżeli w odniesieniu do danego leku wydana została decyzja administracyjna o objęciu go refundacjąjako lekiem dostępnym w aptece na receptę, może on być wydawany świadczeniobiorcy bezpłatnie, za odpłatnością ryczałtowa albo za odpłatnością w wysokości 30\% albo 50\% ich limitu finansowania - do wysokości limitu finansowania i za dopłatą w wysokości różnicy między cena detaliczną a wysokościa limitu finansowania (art. 6 ust. 2 u.r.). Jako punkt odniesienia przy określaniu odpłatności za lek dostępny w aptece na receptę ustawa wprowadziła pojęcie dobowej dawki leku (DDD) ustalonej przez Światową Organizacje Zdrowia. Z tego względu w art. 6 ust. 3 u.r. postanowiono, że odpłatności, o których mowa w ust. 2, dotyczą jednostkowego opakowania leku, środka spożywczego specjalnego przeznaczenia żywieniowego oraz jednostkowego wyrobu medycznego, z tym że odpłatność ryczałtowa dotyczy jednostkowego opakowania leku zawierającego nie więcej niż 30 DDD, a w przypadku większej liczby DDD w opakowaniu odpłatność ta zwiększana jest proporcjonalnie do ilorazu liczby DDD w opakowaniu i 30 DDD. W przypadku leku, dla którego DDD nie zostało określone, odpłatność ryczałtowa dotyczy natomiast jednostkowego opakowania leku wystarczającego na miesięczną terapię lub stosowanie. Ponadto na mocy art. 6 ust. 5 u.r. leki recepturowe (tj. leki sporządzone $\mathrm{w}$ aptece na podstawie recepty lekarskiej) przygotowane $\mathrm{z}$ surowców farmaceutycznych lub z leków gotowych, dla których została wydana decyzja administracyjna o objęciu refundacja, są wydawane świadczeniobiorcy za odpłatnością ryczałtowa, pod warunkiem że przepisana dawka leku recepturowego jest mniejsza od najmniejszej dawki leku gotowego w formie stałej stosowanej doustnie.

Z kolei wysokość odpłatności ryczałtowej została określona dwojako. Co do zasady wynosi ona 3,20 zł (art. 6 ust. 6 u.r.), natomiast w odniesieniu do leków recepturowych wydawanych na podstawie art. 6 ust. 5 u.r. - 0,50\% wysokości minimalnego wynagrodzenia za prace ogłaszanego w obwieszczeniu Prezesa Rady Ministrów wydanym na podstawie art. 2 ust. 4 ustawy z 10 października 2002 r. o minimalnym wynagrodzeniu za pracę ${ }^{16}$, z zaokragleniem do pierwszego miejsca po przecinku ${ }^{17}$. Wykaz leków, które mogą być traktowane jako surowce farmaceutyczne przy sporządzaniu leków recepturowych, ilość leku recepturowego, którego dotyczy odpłatność ryczałtowa, oraz sposób oblicza-

\footnotetext{
15 Zgodnie z art. 2 pkt 18 program lekowy to program zdrowotny w rozumieniu przepisów ustawy z 27 sierpnia 2004 r. o świadczeniach opieki zdrowotnej finansowanych ze środków publicznych obejmujący technologię lekowa, w której substancja czynna nie jest składową kosztową innych świadczeń gwarantowanych w rozumieniu tej ustawy.

16 Dz. U. Nr 200, poz. 1679; 2004, Nr 240, poz. 2407 oraz Dz. U. 2005, Nr 157, poz. 1314.

17 Obecnie wynosi ona zatem 8,00 zł, od 1 stycznia 2014 r. wzrośnie do 8,40 zł.
} 
nia kosztu sporządzania leku recepturowego określa rozporządzenie Ministra Zdrowia ${ }^{18}$. W stosunku do dwóch kolejnych kategorii dostępności refundacyjnej, tj. leków stosowanych w ramach programu lekowego i leków stosowanych w ramach chemioterapii, art. 6 ust. 8 u.r. stanowi, że są one wydawane świadczeniobiorcy bezpłatnie.

Podstawą do objęcia leku refundacją jest decyzja administracyjna ministra właściwego do spraw zdrowia, zawierająca m.in. kategorię dostępności refundacyjnej, poziom odpłatności oraz tzw. instrumenty dzielenia ryzyka (art. 11 ust. 1 i 2 u.r.). Wspomniane instrumenty dzielenia ryzyka zgodnie z art. 11 ust. 5 u.r. moga dotyczyć uzależnienia wielkości przychodu wnioskodawcy ${ }^{19}$ od uzyskiwanych efektów zdrowotnych; uzależnienia wysokości urzędowej ceny zbytu od zapewnienia przez wnioskodawcę dostaw po obniżonej ustalonej w negocjacjach cenie leku, środka spożywczego specjalnego przeznaczenia żywieniowego oraz wyrobu medycznego; uzależnienia wysokości urzędowej ceny zbytu od wielkości obrotu lekiem, środkiem spożywczym specjalnego przeznaczenia żywieniowego oraz wyrobem medycznym; uzależnienia wysokości urzędowej ceny zbytu od zwrotu części uzyskanej refundacji podmiotowi zobowiązanemu do finansowania świadczeń ze środków publicznych; względnie ustalenia innych warunków refundacji mających wpływ na zwiększenie dostępności do świadczeń gwarantowanych lub obniżenie kosztów tych świadczeń. W kontekście przedmiotu niniejszego opracowania należy zwrócić uwagę zwłaszcza na ten ostatni instrument, wprost nawiązujący do art. 68 ust. 2 Konstytucji RP i statuowanej w nim zasady równego dostępu do świadczeń opieki zdrowotnej finansowanej ze środków publicznych.

W tym świetle należy także wskazać na regulację dotycząca okresu obowiązywania decyzji refundacyjnej, a zwłaszcza negatywne przesłanki jego skracania. Okres obowiązywania decyzji jest zróżnicowany, wynosi 2, 3 lub 5 lat, a uzależnione jest to od okresu nieprzerwanego obowiązywania decyzji dla odpowiednika refundowanego w ramach tej samej kategorii dostępności refundacyjnej i w tym samym wskazaniu, przy czym okres obowiąywania decyzji nie może przekraczać terminu wygaśnięcia okresu wyłączności rynkowej (art. 11 ust. 3 u.r.). Natomiast zgodnie z art. 11 ust. 10 i 11 u.r. skrócenie okresu obowiązywania decyzji następuje w drodze decyzji ministra właściwego do spraw zdrowia, przy czym ma on obowiązek odmówić wydania tej decyzji, jeżeli jej wydanie spowodowałoby istotne ograniczenie dostępności

\footnotetext{
${ }^{18}$ Rozporządzenie Ministra Zdrowia z 6 listopada 2012 r. w sprawie leków, które mogą być traktowane jako surowce farmaceutyczne przy sporządzaniu leków recepturowych, Dz. U. 2012, poz. 1259.

${ }^{19}$ Którym, zgodnie z art. 2 pkt 27 u.r., jest podmiot odpowiedzialny (w rozumieniu ustawy z 6 września 2001 r. - Prawo farmaceutyczne, Dz. U. 2008, Nr 45, poz. 271 ze zm.), przedstawiciel podmiotu odpowiedzialnego, podmiot uprawniony do importu równoległego (w rozumieniu ustawy z 6 września 2001 r. - Prawo farmaceutyczne), wytwórcę wyrobów medycznych, jego autoryzowanego przedstawiciela, dystrybutora albo importera, w rozumieniu ustawy z 20 maja $2010 \mathrm{r}$. o wyrobach medycznych (Dz. U. Nr 107, poz. 679 oraz 2011, Nr 102, poz. 586 i Nr 113, poz. 657), a także podmiot działający na rynku spożywczym (w rozumieniu art. 3 pkt 3 rozporządzenia [WE] nr 178/2002 Parlamentu Europejskiego i Rady z 28 stycznia 2002 r. ustanawiającego ogólne zasady i wymagania prawa żywnościowego, powołującego Europejski Urząd do spraw Bezpieczeństwa Żywności oraz ustanawiającego procedury w sprawie bezpieczeństwa żywności, Dz. Urz. UE L 179 z 7 lipca 2007 r., s. 59).
} 
świadczeniobiorców do leków, środków spożywczych specjalnego przeznaczenia żywieniowego, wyrobów medycznych lub znaczny wzrost odpłatności lub dopłat świadczeniobiorców. Widać zatem, że kwestia realizacji wynikającego z art. 68 ust. 2 Konstytucji RP obowiązku ma dla ustawodawcy istotne znaczenie. Chodzi bowiem nie tylko o technicznie rozumianą dostępność, wynikajacca np. z braku zamiennika leku, którego okres obowiązywania decyzji refundacyjnej miałby być skrócony. Warto podkreślić, że ustawodawca zwraca także uwagę na finansowe obciążenia świadczeniobiorców, co wiąże się z zasada równego, bez względu na sytuację materialna, dostępu do świadczeń opieki zdrowotnej.

Trzeba także zauważyć, że zgodnie z art. 12 u.r. minister właściwy do spraw zdrowia wydaje decyzję administracyjna o objęciu refundacja, nie tylko mając na uwadze uzyskanie jak największych efektów zdrowotnych w ramach dostępnych środków publicznych, lecz także uwzględniając szereg innych zdefiniowanych w ustawie kryteriów, w tym także wpływ na wydatki podmiotu zobowiązanego do finansowania świadczeń ze środków publicznych i świadczeniobiorców. Uwzględnienie obciążeń świadczeniobiorców w oczywisty sposób nawiązuje do zasady wynikającej z art. 68 ust. 2 Konstytucji RP.

Kwestia ta jest jednak w szczególny sposób widoczna w kolejnym przepisie ustawy refundacyjnej, który należy przywołać w kontekście tematyki niniejszego opracowania. Adresowany do ministra właściwego do spraw zdrowia art. 14 u.r. zawiera nie tylko upoważnienie do dokonania - w ramach decyzji o objęciu refundacja - kwalifikacji leku do jednego z poziomów odpłatności, wskazuje także kryteria, jakimi ma kierować się właściwy podmiot.

Nawiąując do art. 6 ust. 8 u.r., art. 14 ust. 1 pkt 1 ustawy refundacyjnej nakazuje mu dokonać kwalifikacji jako przysługującego bezpłatnie każdego leku, który ma udowodnioną skuteczność w leczeniu nowotworu złośliwego, zaburzenia psychotycznego, upośledzenia umysłowego lub zaburzenia rozwojowego albo choroby zakaźnej o szczególnym zagrożeniu epidemicznym dla populacji, albo leku stosowanego w ramach programu lekowego.

W kolejnych punktach ustawodawca precyzuje natomiast zasady kwalifikacji leku do pozostałych poziomów odpłatności, odnosząc się do (nieznanego poprzedniej regulacji, koncentrujacej się na kwestiach medycznego przeznaczenia leku) kryterium kosztu terapii i jego relacji do minimalnego wynagrodzenia za pracę. Otóż w sytuacji, gdy lek wymaga, zgodnie z aktualną wiedza medyczna, stosowania nie dłużej niż 30 dni, ma on zostać przypisany do poziomu refundacji wynoszącego 50\% (art. 14 ust. 1 pkt 3 u.r.). W przypadku konieczności dłuższej terapii danym lekiem, gdy jednocześnie dla świadczeniobiorcy miesięczny koszt stosowania takiego leku przy odpłatności 30\% limitu finansowania przekraczałby 5\% minimalnego wynagrodzenia za pracę, art. 14 ust. 1 pkt 2 ppkt a u.r. przewiduje odpłatność ryczałtowa (3,20 lub 0,50\% minimalnego wynagrodzenia za pracę). Zakwalifikowanie jako leku dostępnego za ryczałtową odpłatnością dotyczy także sytuacji, w której, zgodnie z aktualna wiedzą medyczna, jego stosowanie nie jest konieczne przez dłużej niż 30 dni oraz koszt jego stosowania dla świadczeniobiorcy przy odpłatności 50\% limitu finansowania przekraczałby 30\% minimalnego wynagrodzenia za pracę (art. 14 ust. 1 pkt 2 ppkt c u.r.). Ponadto art. 14 ust. 1 pkt 2 ppkt b u.r. prze- 
widuje, że odpłatność ryczałtowa dotyczy leków zawartych w wykazie leków podstawowych, o którym mowa w art. 36 ust. 5 pkt 1 u.ś.o.z., oraz leków zawartych w wykazie, o którym mowa w art. 37 ust. 2 pkt 2 u.ś.o.z., w brzmieniu obowiąującym przed dniem wejścia w życie ustawy refundacyjnej wydawanych za odpłatnością ryczałtowa, jeśli zgodnie z aktualną wiedzą medyczną stosuje się je dłużej niż 30 dni. Jeżeli lek nie został zakwalifikowany do poziomów odpłatności określonych w pkt 1-3, to art. 14 ust. 1 pkt 4 u.r. nakazuje przypisać go do poziomu refundacji wynoszacego $30 \%$.

Kwalifikacji do odpowiedniej odpłatności dokonuje się przy założeniu stosowania jednej dobowej dawki leku dobowo. W przypadku braku dobowej dawki leku kwalifikacji dokonuje się, opierając się na koszcie miesięcznej terapii.

\section{NOWE PRZEPISY O REFUNDACJI LEKÓW A REALIZACJA KONSTYTUCYJNEGO OBOWIAZZKU DYNAMICZNEGO ZAPEWNIANIA OBYWATELOM RÓWNEGO DOSTĘPU DO ŚWIADCZEŃ OPIEKI ZDROWOTNEJ FINANSOWANEJ ZE ŚRODKÓW PUBLICZNYCH}

Artykuł 68 ust. 2 Konstytucji RP statuuje expressis verbis obowiązek władz publicznych zapewnienia obywatelom równego dostępu do świadczeń opieki zdrowotnej finansowanej ze środków publicznych „niezależnie od ich sytuacji materialnej”. Abstrahując od kontrowersji dotyczących koncepcji i konstrukcji składki na ubezpieczenie zdrowotne jako „ceny” ustawowej gwarancji i udziału w systemie opieki zdrowotnej oraz jej charakteru prawnego ${ }^{20}$, w kontekście niniejszego opracowania należy zwrócić uwagę na ważki w praktyce problem równego dostępu do świadczeń i odnieść się do - warunkowanej ekonomicznie możliwości korzystania $\mathrm{z}$ gwarantowanej systemowo opieki $\mathrm{w}$ fazie realizacyjnej. Przez dostęp do świadczeń opieki zdrowotnej należy bowiem rozumieć nie tylko dostęp do samego systemu, ale także dostęp do opieki zdrowotnej dla jego uczestników. Ma on być równy, w szczególności niezależny od sytuacji materialnej poszczególnych beneficjentów systemu. Tymczasem koszt zaopatrzenia w leki jest znaczącym obciążeniem finansowym świadczeniobiorców. Media nieustannie donoszą o przypadkach pacjentów, którzy nie są w stanie samodzielnie sfinansować zakupu zaordynowanych przez lekarza leków. W takim stanie rzeczy uzasadnione jest ustosunkowanie się do kwestii, czy uregulowane w ustawie refundacyjnej zasady współfinansowania/refundacji leków ze środków publicznych urzeczywistniają zasadę równego dostępu.

Ponoszenie przez świadczeniobiorców części kosztów niektórych świadczeń - o czym wspomina również cytowana literatura ${ }^{21}$ - jest przyjętym w wielu systemach rozwiązaniem chroniącym przez nadużywaniem uprawnień (np. nadmierną konsumpcją leków) i wpływającym na zachowania świadcze-

${ }^{20}$ Zagadnienia te zostały szczegółowo omówione w odrębnym opracowaniu - por. D. E. Lach, op. cit., s. 286-335.

${ }^{21}$ Por. ibidem, s. 96-108, 201-242 i 349 i n. 
niobiorców (np. niewysoka opłata za wizytę u lekarza ma służyć zracjonalizowaniu korzystania z porad). Nie zmienia to faktu, że - nawet uzasadnione organizacyjnie i ekonomicznie - rozwiązania na szczeblu ustawy nie powinny być sprzeczne z wytycznymi konstytucyjnymi. Tymczasem należy zgodzić się z J. Jończykiem ${ }^{22}$, że zasada równego dostępu wynikająca z obowiązków nałożonych na władze publiczne w art. 68 ust. 2 Konstytucji RP statuuje w istocie rzeczy zakaz różnicowania obywateli według kryterium sytuacji materialnej, a co za tym idzie - zabrania wprowadzania wszelakich barier finansowych dotyczących dostępu do świadczeń, w tym udziału własnego w kosztach świadczenia, opłat za wizytę, za wystawienie recepty itp. Na tle regulacji zawartej poprzednio w ustawie zdrowotnej uzasadniona była teza, że przyjęty w niej wzorzec współfinansowania (odpłatności) - polegający na tym, że każdy świadczeniobiorca, niezależnie od jego sytuacji materialnej, w takim samym stopniu (ułamku, kwocie) ponosi ciężar określonych świadczeń - mógłby zostać oceniony jako naruszający zasadę równego dostępu. W poprzednim, jak zresztą i w aktualnym stanie prawnym, ceny leków oraz przewidziany przepisami ustawy udział świadczeniobiorcy w kosztach ich nabycia sa takie same dla wszystkich (identyczne), co jednak nie oznacza, że równe. Od stopnia indywidualnej zamożności (a zróżnicowanie w tym zakresie jest znaczne) zależy bowiem, w jakim stopniu dla danego świadczeniobiorcy ustawowo przewidziany udział w kosztach będzie odczuwalny, względnie czy dany świadczeniobiorca w ogóle będzie mógł sobie na jego poniesienie pozwolić ${ }^{23}$.

Należy jednak mieć na uwadze, że według ustawy zdrowotnej udział w kosztach nabycia leków był zróżnicowany z punktu widzenia rodzaju leku i jego zakwalifikowania jako podstawowego lub uzupełniającego, a zatem odwoływał się wyłącznie do kryteriów medycznych, abstrahując od kwestii sytuacji materialnej świadczeniobiorców. W nowym stanie prawnym jest zgoła inaczej. Ustawa refundacyjna odwołuje się bowiem w art. 14 do kryterium obciążenia świadczeniobiorcy kosztami terapii, uwzględniając dwa czynniki: długość jej trwania (do 30 dni lub powyżej) oraz relację miesięcznego kosztu stosowania danego leku do minimalnego wynagrodzenia za pracę, przy zastosowaniu określonych limitów finansowania. Innymi słowy: im krócej stosowany jest dany lek, tym niższy może być poziom jego refundacji, gdyż relatywne obciążenie budżetu świadczeniobiorcy jest niewysokie. Gdy w grę wchodzi natomiast długie stosowanie danego leku (w praktyce chodzi przede wszystkim o schorzenia przewlekłe), wówczas próg obciążenia świadczeniobiorcy kosztami terapii, którego przekroczenie obliguje ministra zdrowia do zakwalifikowania leku do ryczałtowego poziomu odpłatności ${ }^{24}$, jest znacznie niższy. Jak już bowiem wskazano, odpłatność ryczałtowa dotyczy sytuacji, w której przy stosowaniu danego leku nie dłużej niż 30 dni (przy przyjęciu odpłatności 50\%

${ }_{22}$ Por. np. J. Jończyk, glosa do wyroku SN z 12 lutego 2004 r., II UK 243/03, OSP 2004, nr 10, s. 130 i n.

${ }^{23}$ Por. D. E. Lach, op. cit., s. 349-350.

${ }^{24}$ Na marginesie jedynie należy także zauważyć, że wysokość odpłatności ryczałtowej jest pod rządami ustawy refundacyjnej niższa niż w myśl przepisów ustawy zdrowotnej i wynosi 3,20 zł zamiast $4,25 \mathrm{zl}$, a w odniesieniu do leków recepturowych została wprost powiązana z minimalnym wynagrodzeniem za pracę i wynosi jego 0,50\% (aktualnie 8,00 zł) zamiast sztywno określonej (wprawdzie z zastrzeżeniem waloryzacji) kwoty 12,74 zł. 
limitu finansowania) koszt dla świadczeniobiorcy przekraczałby $30 \%$ minimalnego wynagrodzenia za pracę ${ }^{25}$, lub też w której przy stosowaniu danego leku dłużej niż 30 dni (przy przyjęciu odpłatności 30\% limitu finansowania) miesięczny koszt dla świadczeniobiorcy przekraczałby $5 \%$ minimalnego wynagrodzenia za pracę ${ }^{26}$. Przyjęte rozwiązania uwzględniają zatem zróżnicowanie sytuacji materialnej świadczeniobiorców.

Oczywiście omawiana regulacja nie prowadzi do zupełnego zrównania dostępu do świadczeń opieki zdrowotnej w fazie realizacyjnej (w tym przypadku ciężaru kosztów nabycia leków), nie jest to zresztą zapewne w ogóle możliwe. Niemniej należy w niej widzieć próbę - wynikająca z zawartej w art. 68 ust. 2 Konstytucji RP normy programowej o charakterze (strukturze) normy optymalizacyjnej - zrealizowania zasady równego dostępu w wyższym niż dotąd stopniu przez (przynajmniej częściowe) wyeliminowanie podnoszonych w dotychczasowym stanie prawnym stanów nierówności. Jeżeli bowiem z przepisu art. 68 ust. 2 Konstytucji RP można wywieść normę wyznaczającą władzy publicznej określone zadania i nakazującą ustawodawcy działać w celu „zapewnienia równego dostępu" (tj. z punktu widzenia treści nałożonego obowiązku normę programowa), to należy w konsekwencji uznać, że z obowiązku tego wynika refleks prawa przedmiotowego oznaczający zakaz tworzenia takiej regulacji prawnej, która w nieuzasadniony sposób różnicowałaby dostęp do świadczeń opieki zdrowotnej finansowanej ze środków publicznych w zależności od sytuacji materialnej obywateli. Należy przez to rozumieć przede wszystkim wprowadzanie nieusprawiedliwionych barier finansowych dotyczacych dostępu do świadczeń. Nie zmienia to faktu, że wprowadzenie takich instrumentów, jak np. współudział świadczeniobiorców w kosztach nabycia leków, znajduje uzasadnienie w związanej z zasadami sprawiedliwości społecznej zasadzie dobra wspólnego i prymacie interesu wspólnoty beneficjentów nad interesem pacjentów, a wynika z ograniczoności środków i dążenia do zapewnienia podmiotom uprawnionym do świadczeń opieki zdrowotnej możliwie szerokiej gwarancji systemowej. Niemniej ustawodawca powinien, dążąc do tego, by zasada równego dostępu była realizowana w możliwie najwyższym stopniu, ustawicznie monitorować i usprawniać przyjęte rozwiąania.

Regulacja ustawy refundacyjnej, dotyczaca refundacji leków, może być postrzegana jako pozytywny przykład takiego właśnie działania ustawodawcy. Wprawdzie wprowadzenie nowych zasad refundacji spowodowało w wielu przypadkach wzrost kosztów po stronie świadczeniobiorców (z powodu uwzględniania kosztów miesięcznej terapii szereg leków zostało przekwalifikowanych z poziomu odpłatności ryczałtowej na odpłatność 50\% lub 30\%), niewątpliwie jednak miały miejsce także sytuacje odwrotne. Stwierdzenie, że zmiana zasad skutkowała (także) wystapieniem zmian niekorzystnych dla niektórych świadczeniobiorców, nie powinno jednak rzutować negatywnie na ocenę samej reformy systemu refundacji leków.

Należy mieć bowiem na uwadze, że w odniesieniu do prowadzonej polityki społecznej w ogóle, a gdy idzie o system opieki zdrowotnej w szczególności, ustawodawca stoi wobec dylematu ,godzenia niespójnych celów”27. Z jednej

${ }^{25}$ Obecnie jest to $480 \mathrm{zł}$, od 1 stycznia 2014 r. wzrośnie do 504 zł.

${ }^{26}$ Obecnie jest to $80 \mathrm{zl}$, od 1 stycznia 2014 r. wzrośnie do $84 \mathrm{zl}$.

27 Por. K. Baka et al., op. cit., komentarz do art. 6 pkt 1. 
strony powinien on zagwarantować dostęp równy, a w każdym razie niezależny od sytuacji materialnej, musi zatem oceniać i uwzględniać możliwości finansowe systemu (stąd np. ustawowo określony całkowity budżet na refundację) i jego uczestników (ceny i marże urzędowe, kryteria określania poziomów odpłatności itp.). Z drugiej zaś - napotyka oczekiwania (często nierealistyczne) wyborców/beneficjentów systemu dotyczące katalogu świadczeń gwarantowanych. Przewidując szeroki zakres świadczeń (także odnośnie do zaopatrzenia w leki), a dysponując ograniczonymi środkami (zarówno w ogóle, jak i tymi przeznaczonymi na refundację leków - art. 3 u.r.), ustawodawca musi limitować dostęp, m.in. przez ryczałtowo określony współudział świadczeniobiorców w kosztach, co wobec ich zróżnicowanej sytuacji materialnej różnicuje dostęp. Dotyczyło to zarówno regulacji ustawy zdrowotnej odwołujacej się przy ustalania poziomu refundacji do kryteriów medycznych, jak i, choć w mniejszym stopniu, ma miejsce w odniesieniu do ustawy refundacyjnej i zastosowanego w niej kryterium kosztów terapii i stopnia obciążenia świadczeniobiorcy. Niemniej można jednak uznać, że ani przed 1 stycznia 2012 r., ani po tej dacie przyjęty system refundacji leków nie narusza konstytucyjnej zasady równego dostępu. Jego uzasadnieniem pozostaje bowiem zasada dobra wspólnego, wywiedziona z zasad sprawiedliwości społecznej. Zgodnie z nią interes wspólnoty beneficjentów systemu przeważa nad interesem poszczególnych świadczeniobiorców lub pacjentów. Z tego też względu zrezygnowano z objęcia gwarancja jedynie elementarnego minimum, na które w ramach posiadanych środków można by sobie, bez ograniczania do nich dostępu, pozwolić, decydujac się na maksymalne rozszerzenie kręgu gwarantowanych świadczeń. To jednak wiąże się z koniecznością wbudowania mechanizmów limitujących dostęp (których skutkiem sa np. listy oczekujaccych) lub racjonalizujacych korzystanie ze świadczeń (tak bowiem należy rozumieć rozwiązanie przewidujące ponoszenie przez świadczeniobiorców kosztów nabycia leków), aby nie doprowadzić do zapaści finansowej systemu.

O ile jednak konieczność istnienia takich mechanizmów wobec decyzji o szerokim zakresie przedmiotowym systemu jest oczywista i trudno spodziewać się, że zostaną zarzucone, o tyle rozwiązania szczegółowe dotyczące współpłacenia za leki (tryb, zasady i wytyczne dotyczace wydawania decyzji refundacyjnych, kryteria dotyczące przypisywania leków do konkretnych poziomów refundacji itp.), wprost rzutujące na obciążenia finansowe świadczeniobiorców, mają dla oceny konstytucyjności systemu istotne znaczenie. Z tego powodu należy pozytywnie ocenić dokonane w zakresie refundacji leków zmiany, gdyż regulacja ustawy refundacyjnej w pełniejszym stopniu niż uchylone przepisy ustawy zdrowotnej realizuje wywiedziony z art. 68 ust. 2 Konstytucji RP nakaz zorganizowania systemu opieki zdrowotnej w sposób zapewniający równy - niezależny od sytuacji materialnej - dostęp do świadczeń opieki zdrowotnej finansowanej ze środków publicznych.

dr hab. Daniel Eryk Lach

Profesor Uniwersytetu im. Adama Mickiewicza w Poznaniu lach@amu.edu.pl 


\section{REIMBURSEMENT FOR MEDICATIONS AND EQUAL ACCESS TO HEALTH CARE}

Summary

The author analyses the rules of reimbursement for medications contained in the Reimbursement Act of 12 May 2011, against the background of the regulations of the Health Act of 27 August 2004, in the context of the constitutional duty to provide citizens with equal access to health care services financed from public funds. He also discusses the dynamics of the performance of the above duty as an example of actions of the legislature aimed to satisfy the provisions of art. 68.2 of Poland's Constitution. 
Copyright of Journal of Law, Economics and Sociology is the property of Faculty of Law and Administration of Adam Mickiewicz University in Poznan and its content may not be copied or emailed to multiple sites or posted to a listserv without the copyright holder's express written permission. However, users may print, download, or email articles for individual use.

Właścicielem praw autorskich do „Ruchu Prawniczego, Ekonomicznego i Socjologicznego” jest Wydział Prawa i Administracji Uniwersytetu im. Adama Mickiewicza w Poznaniu. Zawartość czasopisma nie może być kopiowana, przesyłana do innych stron internetowych bądź zamieszczana na blogach bez pisemnej zgody wydawcy. Niemniej artykuły można drukować, kopiować lub przesyłać w formie elektronicznej na własny użytek. 